\title{
OPTIMIZED PLANNING OF ASSORTMENT PRODUCTION IN FOREST STANDS
}

\author{
Luan Demarco Fiorentin ${ }^{1 *}$, Julio Eduardo Arce ${ }^{2}$, Allan Libanio Pelissari ${ }^{3}$, Rodrigo Otávio Veiga de Miranda ${ }^{4}$, \\ Thais Wisniewski de Freitas 5 \\ ${ }^{1 *}$ Federal University of Paraná, Department of Forest Science, Curitiba, Paraná, Brazil - luandfiorentin@ gmail.com \\ ${ }^{2}$ Federal University of Paraná, Department of Forest Science, Curitiba, Paraná, Brazil - jarce@ufpr.br \\ ${ }^{3}$ Federal University of Paraná, Department of Forest Science, Curitiba, Paraná, Brazil - allanpelissari@gmail.com \\ ${ }^{4}$ Federal University of Uberlândia, Department of Forest Science, Monte Carmelo, Minas Gerais, Brazil - rov_miranda@ yahoo.com.br \\ ${ }^{5}$ Federal University of Paraná, Production Engineering, Curitiba, Paraná, Brazil - thaistwf@ gmail.com
}

Received for publication: 16/03/2018 - Accepted for publication: 05/04/2019

\begin{abstract}
Resumo
Planejamento otimizado da produção de sortimentos em povoamentos florestais. Esta pesquisa objetivou avaliar estratégias de planejamento otimizado e analisar seus desempenhos na produção de madeira. Os dados foram obtidos em povoamentos de Pinus spp. de uma empresa florestal com área plantada desequilibrada ao longo do tempo. Modelos para maximizar a produção florestal (1) e o valor presente líquido (2) foram formulados e duas funções objetivo de minimização dos desvios da produção (3) e da oscilação máxima e mínima da produção (4) foram testadas como alternativa aos modelos tradicionais de maximização. A maior área média de desbastes e de corte raso foi obtida na estratégia 1. As estratégias 1 e 2 resultaram em maior variabilidade das operações florestais de desbaste e corte raso. Todas as estratégias acarretaram maior produção de madeira para serraria e serraria especial e menor para laminação, enquanto o volume de celulose foi aproximadamente constante. As estratégias 1 e 2 proporcionaram maior volume médio de sortimentos e alta variabilidade de produção. As estratégias 3 e 4 foram mais eficientes em relação as de maximização, pois supriram a demanda industrial com produção mais homogênea.
\end{abstract}

Palavras-chave: Pesquisa operacional; Programação linear; Manejo florestal.

\begin{abstract}
This study aimed to evaluated two optimized planning strategies and analyze their performance in timber production. Data were obtained in Pinus spp. stands from a forestry company with unbalanced planted area over time. Maximization models of forest production (1) and net present value (2) were formulated and two minimization objective functions of the production deviation (3) and minimum and maximum production oscillation (4) were tested as alternatives to the traditional models. The highest thinning and clearcutting average areas were obtained in strategy 1 . Strategies 1 and 2 resulted in the greatest variability of forestry operations. All strategies resulted in the highest timber production for sawn and special sawn wood and the lowest for veneer, while the pulpwood volume was almost constant. Strategies 1 and 2 provided the highest average timber volume and the greatest variability in the production, while strategies 3 and 4 were more efficient, since they supplied the industrial demand with homogeneous production.

Keywords: Operational research; Linear programming; Forest management.
\end{abstract}

\section{INTRODUCTION}

Pinus stands are intensively cultivated in southern Brazil due to their high economic potential and their excellent adaptability to edaphoclimatic conditions (VASQUES et al., 2007), especially in the states of Paraná and Santa Catarina. According to information from the Brazilian Tree Industry (IBÁ, 2017) from the base year 2016, the Pinus elliottii Engelm and Pinus taeda L. planted area corresponds to over 1.6 million hectares, representing $20.4 \%$ of the total planted forest area in the country. However, the rapid expansion of forest plantations in recent decades has led to an imbalance in planted area, resulting in strategic planning problems for several timber sector companies.

As a result of the abovementioned problem, there has been a significant increase in the complexity of forest planning in recent years (NORDSTRÖM et al., 2013), which requires developing and improving planning techniques. According to Borges et al. (2014), problems in forest planning also include long-term optimization of forestry activities, in which detailed information on the location, intensity and application timing of these operations is required. In addition, there are also difficulties involving transporting forest products to industries and optimizing complex industrial processes.

FLORESTA, Curitiba, PR, v. 49, n. 4, p. 735 - 744, out/dez 2019.

Fiorentin, L. D. et.al.

ISSN eletrônico 1982-4688

DOI: $10.5380 /$ rf.v49 i4.58454 
In addition, sustainable wood production for assorted products (multi-products) is directly related to detailed and accurate planning of all thinning and final harvesting operations. In this sense, Gomide et al. (2013) stressed that harvest planning is a necessary process to ensure balanced production and to determine forest rotation. In addition, it allows introducing new technologies in silviculture and changes in the management regime.

Pinus stands are currently conducted with the purpose of supplying products to various industrial segments and to do so an analysis of wood volume by assortment classes enables planning its economic viability (KOHLER et al., 2014). Thus, it is possible to formulate optimized management plans with guarantees of longterm continuous flow of forest resources, as well as efficient decisions related to forest management.

However, due to fluctuations in the forest market, simulating several management alternatives is essential to ensure the supply of forest industries from different segments. When multiple management systems are evaluated, tools that predict the effects of those systems on the forest and methods which minimize decision makers' subjective preferences become critical (NORDSTRÖM et al., 2013).

Linear programming is a widely applied mathematical technique for solving long-term forest management problems (JOHNSON; SCHEURMANN, 1977). Its use is justified by the linear nature of the objective functions and their restrictions to the main problems of forest activities, as highlighted in Silva et al. (2003) and Campos et al. (2013). In specialized literature, it can be observed that there is a preference of formulating models which maximize financial returns or forest production, such as in Gomide et al. (2010), Gomide et al. (2013), Borges et al. (2014), Hahn et al. (2014) and Pereira et al. (2015). However, only a few models with objective minimization function are found, highlighting those by Bettinger and Zhu (2006) and Bettinger et al. (2014). When properly formulated, minimization models have the potential to ensure stable production flow (FIORENTIN et al., 2017), coupled with low variability in thinning and harvesting operations, which is recommended for operational planning.

Due to the importance of formulating different decision-making scenarios for forest management, especially for Pinus stands under multi-product management, as well as the little amount of research which has been conducted on simultaneous optimization of various classes of wood use, the objective of this study was to analyze the performance of optimized planning strategies in assorted production. In addition, it was hypothesized that the strategies for minimizing deviations (strategy 3) and production oscillation (strategy 4) are more efficient for controlling long-term annual wood flow than traditional maximization models.

\section{MATERIAL AND METHODS}

The data for this study were obtained from a forestry company located in the state of Santa Catarina, southern Brazil. The forest stands were unregulated and predominated the area at various ages (Figure 1). The effective planting area corresponded to 5,786.75 ha, with 4,942.53 ha (85.41\%) of Pinus taeda and 844.22 ha (14.59\%) of Pinus elliottii. Approximately $80 \%$ of the total area had plantings in age classes under 12 years and $16 \%$ over 26 years.

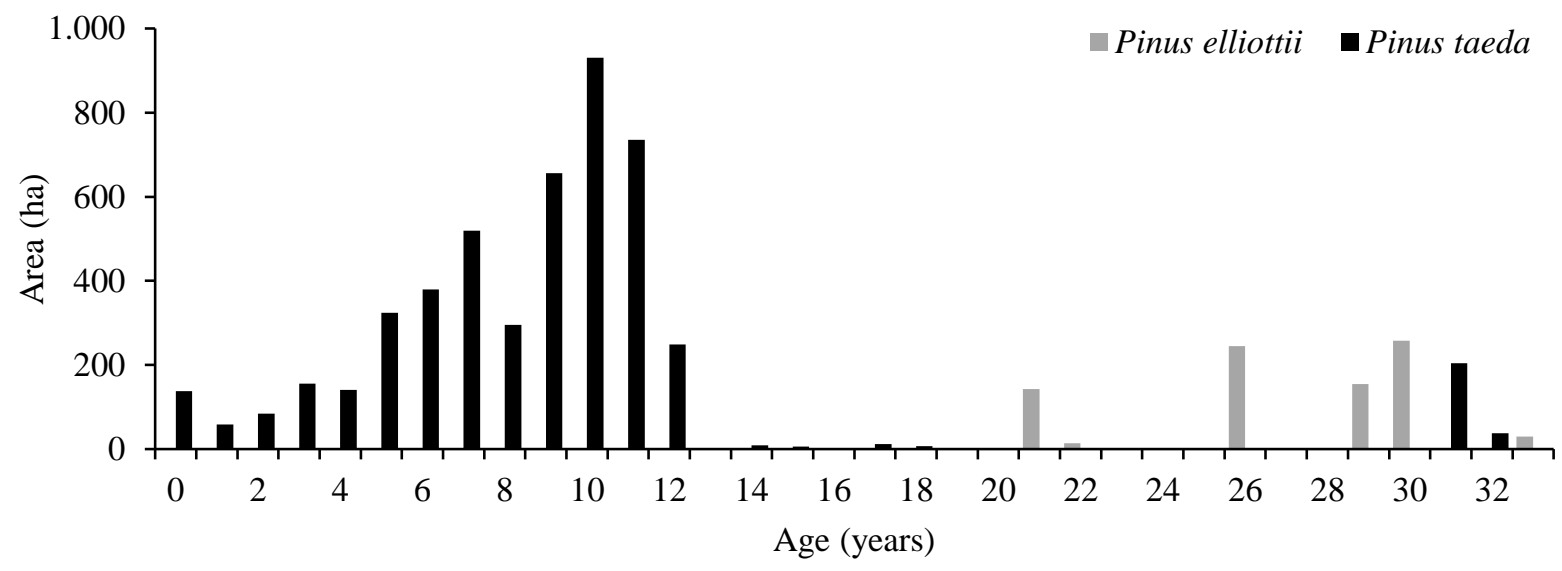

Figura 1. Área plantada de Pinus taeda e Pinus elliottii em diferentes classes de idades.

Figure 1. Planted area of Pinus taeda and Pinus elliottii in different ages classes.

\section{Simulation of management strategies and assortment classes}

Management strategies were simulated for each stand with the purpose of regulating the annual wood production, aiming to generate sustainable production of total commercial volume and/or by long-term assortments. The standard management scenario represented the ideal way of conducting the forest, in which three 
pre-commercial thinning cuts were simulated at the ages of 10,15 and 20 years, while the clearcutting ranged from 24 to 26 years.

Thinning and clearcutting forest operations were relaxed in the first rotation of the implemented stands, as the ages to perform these forest operations were significantly changed for some stands compared to standard management. Thus, the first thinning cuts were applied to stands between 8 and 12 years old; the second between 13 and 17 years old; the third between 18 and 22 years old; and clearcutting to stands between 23 and 27 years old.

Clearcutting stands aged 28 and over has been set to occur within 12 years over the planning horizon. This restriction was necessary to prevent advanced age stands from being indicated for harvest in the early periods. Finally, a restriction was imposed for at least 3 years between consecutive forest operations such as thinning and clearcutting.

Thinning was simulated for all management alternatives as follows: first thinning was systematically selected in the seventh row, with removal of $50 \%$ density (in number of trees per hectare); and second and third selective thinning with removal of $40 \%$ and $30 \%$ of the remaining density, respectively. The initial density was 1,600 trees per hectare.

Assortment classes, dimensions of each wood product and their market value were provided by the forestry company (Table 1). The financial values corresponded to the price of standing wood, commonly used by the company.

Tabela 1. Diâmetro limite, comprimento de tora e preço de mercado para cada classe de sortimento de madeira. Table 1. Diameter limit, log length, and market price for each timber assortment class.

\begin{tabular}{lccc}
\hline \multicolumn{1}{c}{ Assortment class } & Diameter limits $(\mathbf{c m})$ & Log length $(\mathbf{m})$ & Price $\left(\mathbf{R} \mathbf{\text { \$. }}^{\mathbf{- 3}}\right)$ \\
\hline Pulp & {$[8-18)$} & 1.60 & 20.30 \\
Sawn & {$[18-25)$} & 2.50 & 47.20 \\
Specially sawn & {$[25-35)$} & 2.50 & 78.60 \\
Veneer & {$[35+$} & 2.20 & 133.30 \\
\hline
\end{tabular}

\section{Optimized strategic planning strategies}

The formulation of the production regulation problem was based on the Type I model (JOHNSON; SCHEURMANN, 1977). Four optimization strategies (models) were tested, two objective minimization functions and two traditional objective maximization functions.

The notations used to symbolize objective functions and constraints are given below: $\mathrm{PH}=$ planning horizon; NPVi $=$ net present value $(\mathrm{R} \$)$ of the $\mathrm{i}^{\text {th }}$ stand under the $\mathrm{j}^{\text {th }}$ management alternative; VOLijk $=$ volume $\left(\mathrm{m}^{3}\right)$ produced in the $\mathrm{i}^{\text {th }}$ stand submitted to the $\mathrm{j}^{\text {th }}$ management alternative in period $\mathrm{k}$; MinMax $=$ lowest value of maximum PH output; MaxMin = highest value of the lowest possible PH output; DevVol = absolute volume deviation $\left(\mathrm{m}^{3}\right)$ in consecutive years; $\mathrm{Xij}=$ area fraction (ha) of the $\mathrm{i}^{\text {th }}$ stand under the $\mathrm{j}^{\text {th }}$ management alternative; $\mathrm{Ai}=$ total area (ha) of the $\mathrm{i}^{\text {th }}$ stand at the beginning of the planning horizon; $\mathrm{M}=$ total number of stands; and $\mathrm{N}=$ total number of management alternatives for the $\mathrm{i}^{\text {th }}$ stand.

- Strategy 1: maximize production of trading volume or sum of assortments (01):

$$
M a x V O L=\sum_{i=1}^{M} \sum_{j=1}^{N}\left(X_{i j} \sum_{k=1}^{H P} V O L_{i j k}\right)
$$

- $\quad$ Strategy 2: maximize net present value (02):

$\operatorname{Max} V P L=\sum_{i=1}^{M} \sum_{j=1}^{N}\left(V P L_{i j} X_{i j}\right)$

- $\quad$ Strategy 3: minimize the difference between the maximum and minimum annual output (03):

$$
\operatorname{MinDIF}=\operatorname{Min}(\operatorname{MinMax}-\operatorname{MaxMin})
$$

- $\quad$ Strategy 4: minimize the production difference between two consecutive years (04):

$$
\text { MinDES }=\text { DesvVol }
$$

FLORESTA, Curitiba, PR, v. 49, n. 4, p. 735 - 744, out/dez 2019. 
Restriction (05) was imposed on all regulatory strategies and indicated the maximum available area for forest stand operations $i$.

$$
\sum_{j=1}^{N} X_{i j} \leq A_{i}
$$

The supply constraint of industrial wood demand (06) was applied in all optimization strategies. This restriction ensured an average annual flow of $96,000 \mathrm{~m}^{3}$ of sawn wood, specially sawn wood and veneer wood over the planning horizon years. The pulp class was the only one not part of the optimization model, since the company does not use this assortment for internal consumption. Thus, excess wood production from optimized planning and all pulp production was destined for the forestry market, which has already absorbed this excess production in recent years.

$$
\sum_{i=1}^{M} \sum_{j=1}^{N}\left(V O L_{i j k} X_{i j}\right)=96.000 \quad \forall_{k}
$$

Constraints (07) and (08) were modeled together with the objective function (03), ensuring oscillation minimization between the maximum and minimum production obtained in the planning horizon. On the other hand, constraints (09) and (10) were applied in objective function (04), ensuring minimization of absolute production deviations between consecutive years:

$$
\begin{aligned}
& \sum_{i=1}^{M} \sum_{j=1}^{N}\left(\operatorname{VOL}_{i j k} X_{i j}\right) \leq \operatorname{MinMax} \quad \forall_{k} \\
& \sum_{i=1}^{M} \sum_{j=1}^{N}\left(\operatorname{VOL}_{i j k} X_{i j}\right) \geq \operatorname{MaxMin} \quad \forall_{k} \\
& \sum_{i=1}^{M} \sum_{j=1}^{N}\left(V O L_{i j k} X_{i j}\right)-\sum_{i=1}^{M} \sum_{j=1}^{N}\left(V O L_{i j(k-1)} X_{i j}\right)<\text { DesvVol } \quad \forall_{k>1} \\
& \sum_{i=1}^{M} \sum_{j=1}^{N}\left(V O L_{i j(k-1)} X_{i j}\right)-\sum_{i=1}^{M} \sum_{j=1}^{N}\left(V O L_{i j k} X_{i j}\right)<\text { DesvVol } \quad \forall_{k>1}
\end{aligned}
$$

It is important to highlight that the linear programming models did not converge when production limits were entered for each assortment class, meaning that the results became unfeasible. This fact is directly related to the considerably irregular structure of the planting areas over the years. Therefore, it was decided to not insert minimum or maximum assortment demand information in the models, aiming to obtain the best possible results and convergence of the models.

OpTimber-LP ${ }^{\circledR}$ strategic forest planning software was used to solve the optimization problem. It has an interface with the SisPinus ${ }^{\circledR}$ Forest Growth and Production Simulator and LINGO ${ }^{\circledR}$, developed by LINDO Systems INC, for solving linear and non-linear programming problems. The SisPinus ${ }^{\circledR}$ program was used to simulate the different management alternatives for each stand. After the simulation, the scenarios were optimized using LINGO $^{\circledR}$ software. The considered planning horizon was 50 years, with the purpose of ensuring stand regulation in approximately two forest rotations.

The variables used to compare the planning strategies were the average annual area of forest operations and the average annual assortment production, together with the coefficient of variation (\%). The non-parametric Kruskal-Wallis test was applied to verify the existence of differences between the optimization models, while the Simes-Hochberg test was used to compare the area means, both considering $5 \%$ significance. The null hypothesis (H0) formulated expressed the equality between the strategies (e_i), in which i $1,2,3$ and 4, as: $H_{0}: e_{1} ; e_{2} ; e_{3} ; e_{4}$ did not statistically differ and $H_{1}: e_{1} ; e_{2} ; e_{3} ; e_{4}$ statistically differ by at least one of the averages. 


\section{RESULTS}

\section{Effect of planning strategies on forest operations}

Planning strategy 1 provided the largest average area per year for the first, second and third thinning, as well as clearcutting, resulting in a higher produced wood volume. The other strategies presented similar values for forestry operations, especially for second and third thinning, as well as clearcutting (Table 2).

Tabela 2. Área média e coeficiente de variação do primeiro, segundo e terceiro desbastes e do corte raso para cada estratégia de planejamento.

Table 2. Mean area and coefficient of variation of the first, second, and third thinning and clearcutting for each planning strategy.

\begin{tabular}{|c|c|c|c|c|}
\hline Strategy & $1^{\text {st }}$ thinning & $2^{\text {nd }}$ thinning & $3^{\text {rd }}$ thinning & Clearcutting \\
\hline \multicolumn{5}{|c|}{ Mean area $\left(\right.$ ha. $\left.a n o^{-1}\right)$} \\
\hline Strategy1 & 260.54 & 229.75 & 216.78 & 262.53 \\
\hline Strategy 2 & 241.65 & 217.76 & 197.28 & 237.66 \\
\hline Strategy3 & 254.07 & 218.68 & 194.23 & 239.10 \\
\hline Strategy4 & 247.71 & 215.48 & 195.13 & 236.20 \\
\hline \multicolumn{5}{|c|}{ Coefficient of variation $(\%)$} \\
\hline Strategy1 & 100.60 & 127.57 & 111.39 & 133.96 \\
\hline Strategy2 & 66.51 & 87.34 & 91.79 & 62.63 \\
\hline Strategy3 & 58.09 & 73.19 & 83.58 & 42.25 \\
\hline Strategy4 & 56.77 & 68.93 & 77.55 & 33.31 \\
\hline
\end{tabular}

The coefficient of variation of the mean area of forest operations was greater than $30 \%$ for all optimization models, with values greater than $100 \%$ for strategy 1 . Minimization strategies 3 and 4 resulted in lower coefficient of variation values than maximization models, indicating that forest operations were more homogeneous over time. These results are related to the mathematical nature of the formulations, because the minimization models tended to homogenize the forest production.

There was a large amount of area subjected to the first thinning at the beginning of the planning horizon in all optimization strategies (Figure 2). There was subsequently a significant area destined for the second and third thinning. These results can also be attributed to delayed thinning in young stands under 12 years old and to the effect of the considered assortment prices. However, there was no clear pattern of forest operations occurring after these periods.

Strategy 1

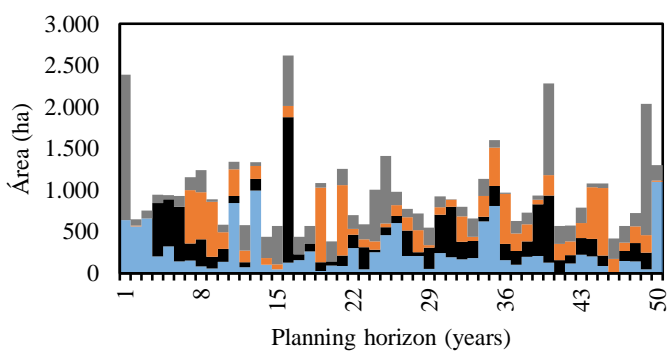

1th thinning

-2nd thinning $\quad 3$ rd thinning $\quad$ Clearcutting

Strategy 3

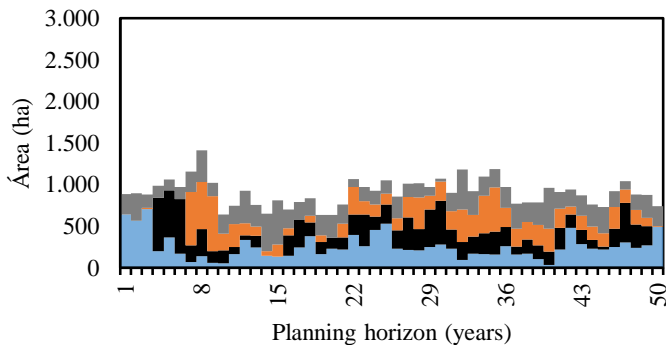

$\square$ th thinning $\quad$ 2nd thinning $\quad$ 3rd thinning $\quad$ Clearcutting
Strategy 2

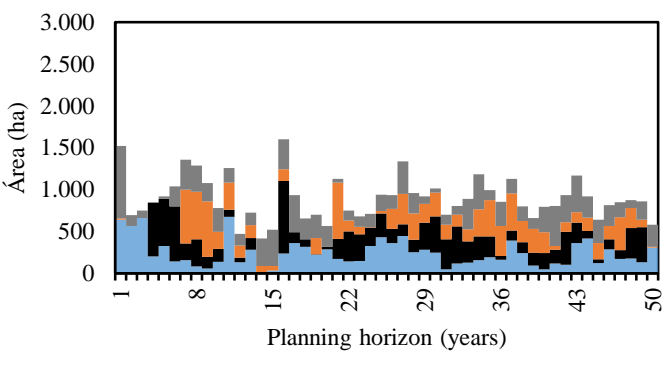

$\square$ th thinning $\quad$ 2nd thinning $\quad$ 3rd thinning $\quad$ Clearcutting

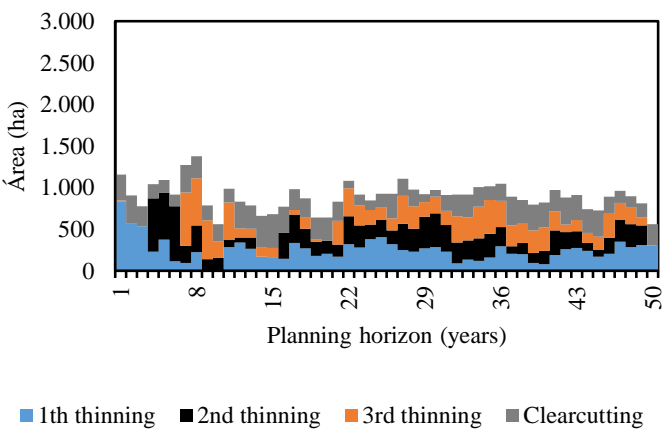

Figura 2. Áreas totais do primeiro, segundo e terceiro desbastes e do corte raso para cada estratégia de planejamento.

Figure 2. Total areas of the first, second, and third thinning and clearcutting for each planning strategy. 
In addition, large areas were selected for clearing at certain periods of the planning horizon. For strategy 1, clearcutting corresponded to over $60 \%$ of forest operations in years 1,15 and 49 of the planning horizon, while this result was observed in years 14 and 15 of the planning horizon for strategies 2 and 3 . As a consequence of these results, high large wood production from the larger assortments is expected.

\section{Effects of planning strategies on assortment production}

The highest average assortment production was obtained in maximization strategies 1 and 2 . This fact was directly related to the higher pulp and sawn wood production in strategy 1 , as well as the high production of special sawn wood in strategy 2 . On the other hand, the total volume variability was lower for minimization strategies 3 and 4 , indicating that yields were more homogeneous over the planning horizon (Table 3).

Tabela 3. Volume de madeira e coeficiente de variação do sortimento de celulose, serraria, serraria especial e laminação para cada estratégia de planejamento.

Table 3. Timber volume and coefficient of variation of the pulpwood, sawn, specially sawn, and veneer assortment for each planning strategy.

\begin{tabular}{|c|c|c|c|c|c|}
\hline Strategy & Pulp & Sawn & Specially sawn & Veneer & Total volume \\
\hline \multicolumn{6}{|c|}{ Mean wood volume $\left(\mathrm{m}^{3} \cdot\right.$ year $\left.^{-1}\right)$} \\
\hline Strategy 1 & $55,310.29$ & $65,789.30$ & $65,546.34$ & $17,937.59$ & $204,583.52$ \\
\hline Strategy 2 & $50,995.86$ & $61,660.75$ & $65,576.80$ & $18,702.11$ & $196,935.52$ \\
\hline Strategy 3 & $52,623.38$ & $61,488.91$ & $61,975.85$ & $17,301.00$ & $193,389.14$ \\
\hline Strategy 4 & $51,746.57$ & $60,474.21$ & $61,174.95$ & $18,537.93$ & $191,933.66$ \\
\hline \multicolumn{6}{|c|}{ Coefficient of variation (\%) } \\
\hline Strategy 1 & 76.70 & 118.55 & 80.28 & 132.59 & 79.87 \\
\hline Strategy 2 & 43.63 & 74.01 & 46.17 & 92.21 & 44.49 \\
\hline Strategy 3 & 36.28 & 53.58 & 37.54 & 82.25 & 23.46 \\
\hline Strategy 4 & 41.17 & 56.82 & 28.74 & 69.44 & 22.43 \\
\hline
\end{tabular}

All planning strategies presented values close to the average wood volume for sawn and specially sawn wood, where the average annual production was always above $60,000 \mathrm{~m}^{3}$. The veneer class presented the lowest average yields when compared to the other assortments, in addition to being the class with the largest oscillations for the different strategies.

The pulp class resulted in homogeneous yields over time due to the lower values of the coefficient of variation, except for strategy 4 , when compared to the other classes. On the other hand, the veneer class generated high coefficient of variation values, followed by the sawn and specially sawn wood class.

The planning strategies reached an annual wood demand of $96,000 \mathrm{~m}^{3} . \mathrm{year}^{-1}$ to supply the industry, where a predominance of sawn and specially sawn wood was observed (Figure 3). Excess production over the years has been destined for sale on the forest markets.

Strategy 1

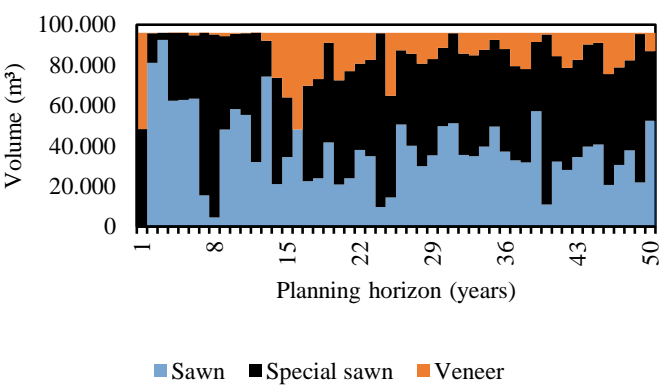

Strategy 3

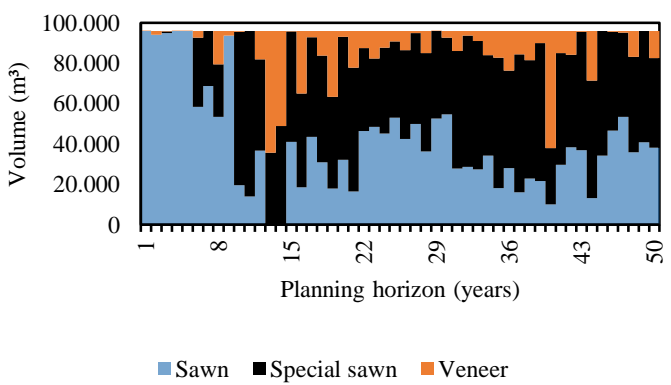

Strategy 2

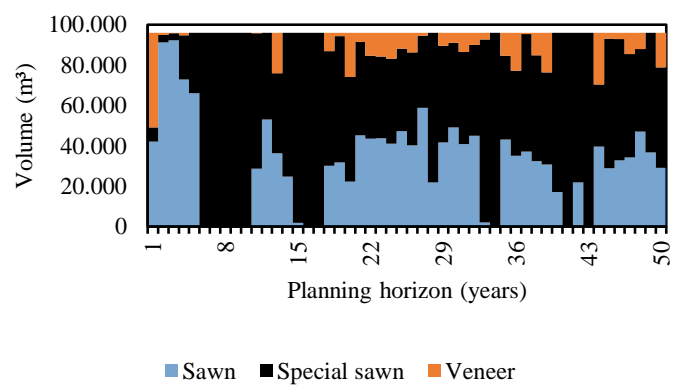

Strategy 4

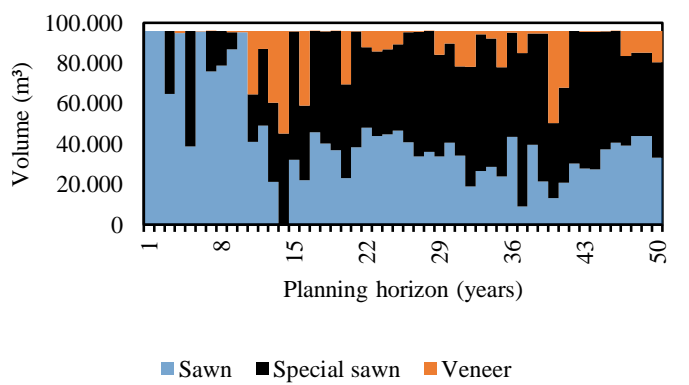


Figura 3. Volume de madeira do sortimento de serraria, serraria especial e laminação destinado para suprir a indústria para cada estratégia de planejamento.

Figure 3. Timber volume of the sawn, specially sawn, and veneer assortment destined for supplying the industry for each planning strategy.

Minimization strategies provided high consumption of sawn wood by the $13^{\text {th }}$ year. There was a subsequent trend towards stabilization in the production of this assortment with less variation between subsequent years. On the other hand, assortment production was more irregular for maximization strategies 1 and 2.

The volume of pulp wood was evidently more constant over the years when compared to the other assortments (Figure 4). However, the largest volume of this assortment class was observed at the beginning of the planning horizon, possibly due to the high amount of area subjected to the first and second thinning.
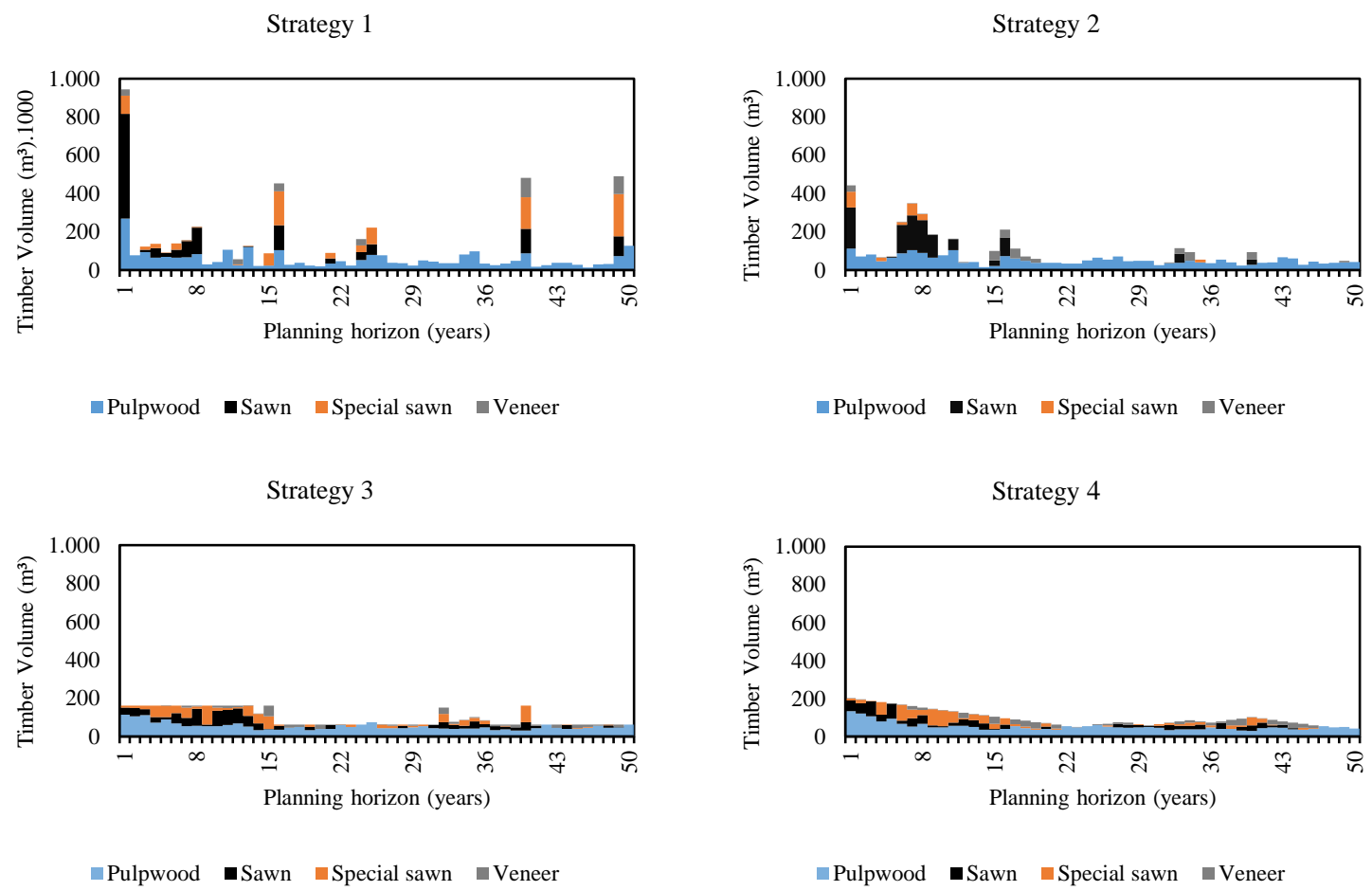

Figura 4. Volume de madeira dos sortimentos de celulose, serraria, serraria especial e laminação destinados para venda em cada estratégia de planejamento.

Figure 4. Timber volume of pulpwood, sawn, specially sawn, and veneer assortment destined for selling in each planning strategy.

For maximization strategies 1 and 2, the pulp class represented the largest percentage of the assortments destined for sale, being exclusively used for commercialization. This proportion was not evident in minimization strategies 3 and 4, in which the other assortments represented higher wood production for sale when compared with the maximization strategies.

\section{Mean comparison test}

The dispersion of the total area values of forest operations was similar in each planning strategy, especially for objective minimization functions 3 and 4 . However, maximization strategies 1 and 2 were more heterogeneous for the total assortment volume, indicating that there was greater variability in volume over the planning horizon (Figure 5). 
Total area

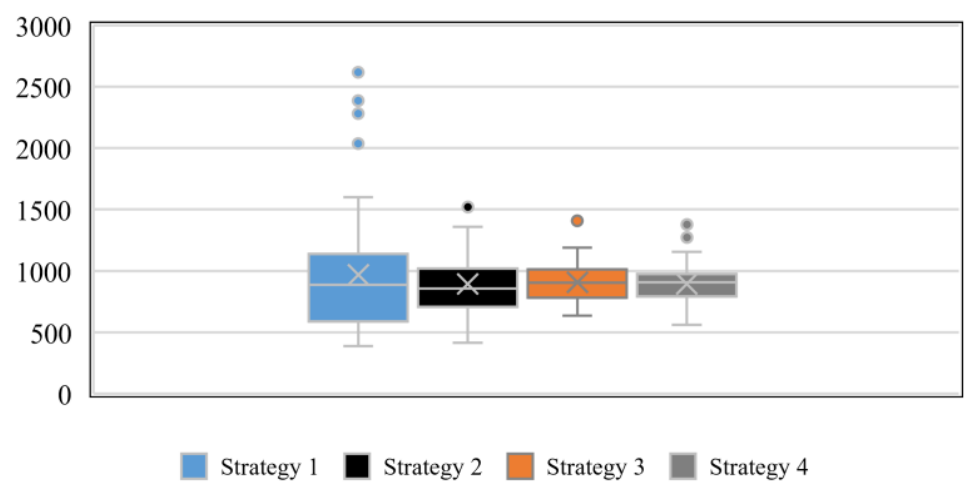

Total volume

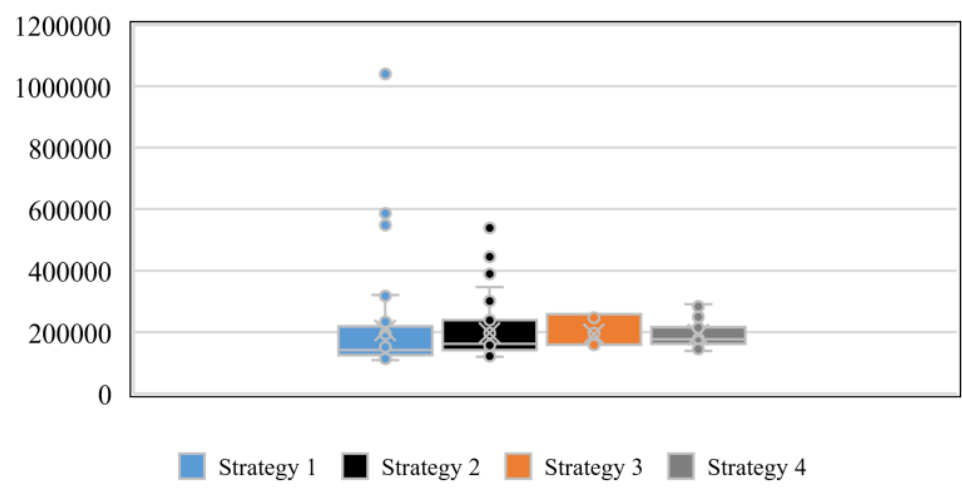

Figura 5. Dispersão da área total de operações florestais e do volume total de sortimentos para cada estratégia de planejamento.

Figure 5. Dispersion of total forest operations area and total assortment volume for each planning strategy.

The Kruskal-Wallis test resulted in a p-value of 0.8313 , indicating that there was no statistically significant difference for the total area of forest operations between the planning strategies. There was a statistically significant difference between the strategies for the total assortment volume, with p-value equal to 0.0028 . The Simes-Hochberg multiple comparison test indicated that there was no statistical difference between strategies 2, 3 and 4 and between strategies 1 and 2, considering a significance level of 5\%.

\section{DISCUSSION}

The results indicated an imbalance in forest operations for maximization strategies, which may result in future operational problems due to overproduction in some periods, limiting the application of these objective functions. The minimization strategies were very promising and have great application potential since they make it possible to reach the wood demand concomitantly with the low variation in forest operations and the total assortment volume, corroborating the formulated hypothesis.

Maximum and minimum wood volume demand restrictions are common in forest harvest optimization work (GOMIDE et al., 2010; GOMIDE et al., 2013), especially to ensure homogeneous productions over the planning horizon. The models in the present work became unfeasible when production flow constraints were introduced, even with large demand values. In this sense, minimization models are highlighted when industrial supply limits are not included, as they are still capable of homogenizing forest production.

Higher pulp production is directly related to the dynamics of this assortment over time. According to Kohler et al. (2015), the pulp class presents regular volume during the growth of Pinus taeda species, resulting in the average of two logs per tree during the development period of the stand. Therefore, it is possible to state that the volume difference of this assortment over time was due to the amount of areas thinned or harvested in each period. Thus, excess pulp production is directly associated with delayed thinning in forest stands. 
In a previous work to the present study, Fiorentin et al. (2017) found that negative net revenue values were found in all formulated optimization strategies in the planning horizon periods where the number of areas subjected to the first thinning was high. The authors attributed these results to the low economic value of pulpwood and the high harvest values associated with the first and second thinning.

The lower volume of wood for the veneer class was related to the absence of large trees in forest stands, which are only obtained at advanced ages. According to Kohler et al. (2015), 31\% of the volume of Pinus taeda individuals aged 19 to 22 correspond to veneer, while $62 \%$ is intended for sawn wood.

The wood class for energy was not considered in this study, as the company does not use this production assortment. However, Karttunen et al. (2016) showed that wood for energy from the first thinning can also be produced profitably. In addition, the authors pointed out that if the energy assortment is profitable and the harvesting cost is considerably lower than that for wood of greater industrial interest, the enterprise may alter their management of forest stands, as well as the use of other assortments by the industry.

Thus, the optimal planning strategy choice must be made based on the enterprise's objectives. Forest planning problems are generally formulated with a view to maximizing variables, either forest production or financial return (BORGES et al., 2014; HAHN et al., 2014). However, the present study showed that the minimization functions, even if little used, can present very satisfactory results in forest production planning.

\section{CONCLUSIONS}

- Strategies for maximizing volume and net present value result in higher volume of sawn and specially sawn wood, while veneer production is lower and with high variability, along with homogeneous pulp production.

- Minimization strategies are efficient in meeting industrial wood demand and reducing the variation in forest operations and assortment volume over the planning horizon. Research is recommended to analyze the performance of minimization models in strategic spatial planning.

- The strategy of minimizing the difference between the maximum and the minimum annual production of wood assortments is the most appropriate to regulate Pinus spp. stands, as it results in constant yields over the planning horizon.

\section{ACKNOWLEDGEMENTS}

The first author expresses gratitude to the National Council for Scientific and Technological Development $(\mathrm{CNPq})$ for granting a doctorate scholarship.

\section{REFERENCES}

BORGES, P.; BERGSENG, E.; EID, T. Adjacency constraints in forestry - a simulated annealing approach comparing different candidate solution generators. Mathematical and Computational Forestry \& Natural Resource Sciences, v. 6, n. 1, p. 11 - 25, 2014.

BETTINGER, P.; ZHU, J. A new heuristic method for solving spatially constrained forest planning problems based on mitigation of infeasibilities radiating outward from a forced choice. Silva Fennica, v. 40, n. 2 , p. 315 333, 2006.

BETTINGER, P.; DEMIRCI, M.; BOSTON, K. Search reversion within s-metaheuristic: impacts illustrated with a forest planning problem. Silva Fennica, v. 49, n. 2, p. 1 - 20, 2014.

CAMPOS, B. P. F.; BINOTI, D. H. B.; SILVA, M. L.; LEITE, H. G.; BINOTI, M. L. M. S. Conversão de árvores em multiprodutos de madeira utilizando programação linear. Revista Árvore, v. 37, n. 15, p. 881 - 887, 2013.

FIORENTIN, L. D.; ARCE, J. E.; PELISSARI, A. L.; DAVID, H. C.; SILVA, P. H. B. M.; STANG, M. B.; FIGUEIREDO FILHO, A. Strategies for regulating timber volume in forest stands. Scientia Forestalis, v. 45, n. 116, p. 717 - 726, 2017.

GOMIDE, L. R.; ARCE, J. E.; SILVA, A. C. L. Efeito das restrições espaciais de adjacência no planejamento florestal otimizado. Floresta, v. 40, n. 3, p. 573 - 584, 2010.

GOMIDE, L. R.; ARCE, J. E.; SILVA, A. C. L. Comparação entre a meta-heurística simulated annealing e a programação linear inteira no agendamento da colheita florestal com restrições de adjacência. Ciência Florestal, v. 23, n. 2, p. 449 - 460, 2013.

FLORESTA, Curitiba, PR, v. 49, n. 4, p. 735 - 744, out/dez 2019. 
HAHN, W. A.; HÄRTL, F.; IRLAND, L. C.; KOHLER, C.; MOSHAMMER, R.; KNOKE, T. Financially optimized management planning under risk aversion results in even-flow sustained timber yield. Forest Policy and Economics, v. 42, p. 30 - 41, 2014.

IBÁ - Industria Brasileira de Árvores. Relatório 2017. Brasília: IBÁ, 2017. 80 p. Disponível em: <http://iba.org/images/shared/Biblioteca/IBA_RelatorioAnual2017.pdf>. Acesso em: 31 jan 2019.

JOHNSON, K. N.; SCHEURMANN, H. L. Techniques for prescribing optimal timber harvest and investment under different objectives - discussion and synthesis. Forest Science, v. 18, n. 1, p. 1 - 31, 1977.

KARTTUNEN, K.; LAITILA, J.; RANTA, T. First-thinning harvesting alternatives for industrial or energy purposes based on regional Scots pine stand simulations in Finland. Silva Fennica, v. 50, n. 2, p. 1 - 16, 2016.

KOHLER, S. V.; KOEHLER, H. S.; FIGUEIREDO FILHO, A.; ARCE, J. E.; MACHADO, S. A. Evolução do sortimento em povoamentos de Pinus taeda nos estados do Paraná e Santa Catarina. Floresta, v. 45, n. 3, p. 545 $554,2015$.

KOHLER, S. V.; WOLF II, N. I; FIGUEIREDO FILHO, A; ARCE, J. E. Dynamic of assortment of Pinus taeda L. plantation in different site classes in Southern Brazil. Scientia Forestalis, v. 42, n. 103, p. 403 - 410, 2014.

NORDSTRÖM, E.; HOLMSTRÖM, H.; ÖHMAN, K. Evaluating continuous cover forest based on forest owner's objectives by combining scenario analysis and multiple criteria decision analysis. Silva Fennica, v. 47, n. 4, p. 1$22,2013$.

PEREIRA, S.; PRIETO, A.; CALAMA, R.; DIAZ-BALTEIRO, L. Optimal management in Pinus pinea L. stands combining silvicultural schedules for timber and cone production. Silva Fennica, v. 49, n. 3, p. 1-16, 2015.

SILVA, G. F.; LEITE, H. G.; SOARES, C. P. B.; SILVA, M. L. Influência de estimativa de produção de madeira em processos de regulação florestal utilizando programação linear. Revista Árvore, v. 13, n. 1, p. 57 - $72,2003$.

VASQUES, G. A.; NOGUEIRA, A. S.; KIRCHNER, F. F.; BERGER, R. Uma síntese da contribuição do gênero Pinus para o desenvolvimento sustentável no Sul do Brasil. Floresta, v. 37, n. 3, p. 445 - 450, 2007. 